\title{
Comparison between in sacco and in vitro protein rumen degradability ${ }^{*}$
}

\author{
S Terramoccia ${ }^{1}, S_{\text {Puppo }}{ }^{1}$, L Rizzi $^{2}$, F Martillotti $^{1}$ \\ 'Istituto Sperimentale per la Zootecnia, Via O Panvinio 11, 00162 Rome; \\ ${ }^{2}$ Istituto di Zootecnia e Nutrizione Animale, Via S Giacomo 11, 40126 Bologna, Italy
}

As in sacco protein rumen degradability (DT) involves a lot of work and time, an enzymatic procedure for DT determination could be a simpler method. A comparison between in sacco and in vitro determination is useful in order to assess the difference.

The study concerned 8 feeds: maize germ (MG), maize gluten meal (MGM), alfalfa dehy (AD), cottonseed meal (CSM), fish meal (FM), full fat soybean (FFSB), extruded soybean (ETSB), flaked soybean (FSB). Each feed was incubated either in sacco ( 3 fistulated dairy cows, $3 \times 3$ replications, nylon bags $16 \times 10 \mathrm{~cm}$ - diam $41 \mu \mathrm{m}$, sample $=$ $3 \mathrm{~g}-2.5 \mathrm{~mm}$ ground) according to Orskov and McDonald (1979) or in vitro (glass tube $=100 \mathrm{ml}$, sample $=1 \mathrm{~g}-1 \mathrm{~mm}$ ground) with Streptomyces griseus protease at $\mathrm{pH} 8.00$ (2 $\mathrm{mg}$ protease/g sample) according to the Aufrere and Cartailler method (1988) modified: $\mathrm{N} \times 6.25$ was determined on feed residue after filtration on crucible $2 \mathrm{G} 2$. The incubation times were: $0,1,2,4,8,16,24$, $48,72 \mathrm{~h}$. Both protein degradability kinetics were computed by the Nocek and English procedure.

In conclusion, in all samples, zero time a of in sacco data was close enough to the in vitro data, except for the 2 full fat samples (FFSB and $M G$ ). The asymptotic data $a+b$ of the in sacco method are always higher than those determined in vitro; such a difference is due to a major number of protein cleavage sites to be attached by protease in the rumen for synergistic action of other enzymes (amylase, cellulase, hemicellulase, etc). None of the in vitro kinetics curves showed lag time; some of the in sacco kinetics had a more or less long lag time. The DT:\% figures of the 2 methods were close enough for $M G, M G M, A D, C S M, F F S B$, but for the other samples the differences were over $10 \%$. The RSD of the in vitro method were always lower than that of the in sacco method.

Although some results are good, the enzymatic method needs to be improved; it seems that the protease, used alone, is not active enough for a complete protein degradation.

\section{Aufrère J, Cartailler D (1988) Ann Zootech 37, 255-270 \\ Orskov ER, McDonald I (1979) J Agric Sci Camb 92, 499-503}

Table I. In sacco / in vitro parameters of degradation and degradability of the feeds.

\begin{tabular}{|c|c|c|c|c|c|c|}
\hline Feed & a & b & $c$ & $R S D$ & $D T / \%(\mathrm{k}=0.05)$ & Diff \% \\
\hline $\begin{array}{l}\text { MG } \\
\text { MGM } \\
\text { AD } \\
\text { CSM } \\
\text { FM } \\
\text { FFSB } \\
\text { ETSB } \\
\text { FSB }\end{array}$ & $\begin{array}{l}40.1 / 67.5 \\
12.7 / 1.7 \\
56.5 / 60.1 \\
56.8 / 55.2 \\
30.8 / 27.9 \\
24.4 / 53.9 \\
12.3 / 12.2 \\
30.6 / 30.0\end{array}$ & $\begin{array}{l}58.9 / 13.4 \\
84.7 / 52.3 \\
36.2 / 23.6 \\
36.4 / 32.6 \\
56.9 / 56.5 \\
74.8 / 16.6 \\
87.6 / 56.7 \\
68.5 / 30.6\end{array}$ & $\begin{array}{l}0.091 / 0.155 \\
0.038 / 0.051 \\
0.082 / 0.155 \\
0.097 / 0.072 \\
0.029 / 0.037 \\
0.075 / 0.062 \\
0.057 / 0.058 \\
0.183 / 0.105\end{array}$ & $\begin{array}{l}1.7 / 1.6 \\
9.5 / 1.7 \\
5.3 / 0.8 \\
5.0 / 1.3 \\
6.5 / 3.3 \\
6.711 .5 \\
8.7 / 2.7 \\
4.3 / 1.7\end{array}$ & $\begin{array}{l}78 / 78 \\
29 / 28 \\
76 / 78 \\
74 / 78 \\
46 / 52 \\
69 / 63 \\
53 / 42 \\
72 / 51\end{array}$ & $\begin{array}{r}- \\
3.4 \\
2.6 \\
5.4 \\
13.0 \\
8.7 \\
20.7 \\
29.2\end{array}$ \\
\hline
\end{tabular}

"Research supported by MPI $40 \%$ project, "Protein evaluation in feeding of ruminants." 